\title{
Oestrus, time of ovulation, ovulation rate and conception rate in progestagen-treated ewes given Gn-RH, Gn-RH analogues and gonadotrophins
}

\author{
J. F. Quirke, J. J. Jennings*, J. P. Hanrahan and J. P. Gosling †
}

The Agricultural Institute, Ballinrobe, Co. Mayo; *The Agricultural Institute, Grange, Dunsany, Co. Meath; $†$ The Biochemistry Department, University College, Galway, Ireland

\begin{abstract}
Summary. The influence of Gn-RH, hCG and a PMSG-hCG mixture (PG600) on the time of ovulation, ovulation rate and on the occurrence of oestrus in ewes treated with progestagen-impregnated sponges for 12 days was examined. The effects of $\mathrm{Gn}$ $\mathrm{RH}$ analogues on plasma $\mathrm{LH}$, oestrus, ovulation and conception rate were also investigated. Six separate experiments were carried out.

When $50 \mu \mathrm{g} \mathrm{Gn}-\mathrm{RH}$ were given $24 \mathrm{~h}$ after sponge removal ovulation occurred in $44-46 \%$ of ewes within $24 \mathrm{~h}$ and in all ewes by $34 \mathrm{~h}$. Gn-RH was a more potent ovulation synchronizer than hCG. Both hCG and PG600 reduced the incidence of overt oestrus. Gn-RH also had this effect in ewes treated during February and May but not in August and September.

Gn-RH analogues given 2 days before sponge removal significantly increased ovulation rate. The display of oestrus was not affected in ewes treated 2 days before sponge removal but was suppressed in $43-69 \%$ of ewes treated with an analogue at the time of sponge removal. Ovulation occurred in $50-62 \%$ of ewes within $30-35 \mathrm{~h}$ of injection of Gn-RH analogues, regardless of the time of their administration. The release of $\mathrm{LH}$ in response to one analogue was not influenced by the presence of the progestagen-impregnated sponge in the vagina. When given a Gn-RH analogue 2 days before sponge removal or at the time of sponge removal 63 and $62 \%$ of mated ewes became pregnant compared with $70 \%$ of control ewes.
\end{abstract}

\section{Introduction}

The importance of follicle-stimulating hormone (FSH) for the process of follicular maturation and of luteinizing hormone (LH) for ovulation in the sheep has been appreciated for a very long time (Nalbandov, 1958). More recently it has also been shown that the interval between the discharge of $\mathrm{LH}$ and release of the egg from the follicle is in the region of 21-26 h (Cumming et al., 1973). The ability of synthetic gonadotrophin-releasing hormone ( $\mathrm{Gn}-\mathrm{RH})$ to trigger the release of both FSH and LH in sheep has been documented in many studies (Ripple, Moyer, Johnson \& Mauer, 1974; Symons, Cunningham \& Saba, 1974; Pelletier, 1976). Analogues of Gn-RH have also been developed and many have been shown to have intense FSH- and LHreleasing properties in several species, including the sheep (Ripple et al., 1973; Fujino et al., 1974; Cruz et al., 1975; Kinder et al., 1976; Willis, London, Williams \& Butt, 1976). The present paper describes the results of a series of experiments which were carried out primarily to examine the effects of $\mathrm{Gn}-\mathrm{RH}$ and two of its analogues on the time of ovulation and ovulation rate in the ewe. The effects of a number of other gonadotrophins were also examined.

\section{Materials and Methods}

\section{Hormones}

Intravaginal sponges containing $60 \mathrm{mg}$ medroxyprogesterone acetate, MAP (Veramix: Upjohn Co. Ltd) were used for 12 days to synchronize oestrus in all experiments. The PMSG 
(Folligon) and hCG (Chorulon) were supplied by Intervet Ltd, Cambridge. The proprietary preparation 'PG 600', also from Intervet Ltd, was supplied in separate doses and each dose was stated to contain 400 i.u. PMSG and 200 i.u. hCG. The synthetic Gn-RH was from Abbott Laboratories (Chicago, Illinois) and the potent Gn-RH analogues, D-Ser (TBU) ${ }^{6}-\mathrm{EA}^{10}$ (Hoe 766) and (D-Ala ${ }^{6}$-des-Gly- $\mathrm{NH}_{2}^{10}$ )-LH-RH-ethylamide (AY-25,205), were from Hoechst AG (Frankfurt) and Ayerst Research Laboratories (Montreal), respectively.

All the hormone preparations were dissolved in sterile water. The PMSG and PG 600 were administered intramuscularly (i.m.) in a volume of $5 \mathrm{ml}$. Synthetic $\mathrm{Gn}-\mathrm{RH}$ and hCG were given i.m. in a $2 \mathrm{ml}$ injection. The Gn-RH analogues were given subcutaneously in $2 \mathrm{ml}$ water.

\section{Experiment $A$}

The purpose of this experiment was to examine the effects of a range of gonadotrophin treatments on the occurrence of oestrus, the time of ovulation and ovulation rate in ewes treated with progestagen-impregnated sponges.

A total of 255 non-lactating ewes was used; they were 1-5 years old and had not lambed during the previous 10 months. Groups of ewes were treated with intravaginal sponges beginning on 16 or 19 February 1974 or on 6 May 1974 . On each occasion the ewes were allocated at random to 4 groups and treated as follows: Group 1 received 500 i.u. PMSG at the time of sponge removal; Group 2 received 500 i.u. PMSG when the sponges were removed and $50 \mu \mathrm{g}$ Gn-RH 24 h later; Group 3 ewes were given 500 i.u. PMSG at sponge removal and 400 i.u. hCG $24 \mathrm{~h}$ later; and Group 4 received a single dose of PG 600 (400 i.u. PMSG + 200 i.u. hCG) when the sponges were removed.

The ewes in each treatment group were allocated at random to one of 5 sub-groups for ovarian examination by laparoscopy, at $48,58,68,78$ and $88 \mathrm{~h}$ after sponge removal, to determine whether ovulation had occurred. All ewes were allowed to run with raddled rams after removal of the sponges and flocks were inspected daily at 10:00 and 16:00 h for 6 days for evidence of mating. Ovulation rate in response to the treatments was determined at laparoscopy (see above) or at slaughter 7-14 days after sponge withdrawal.

\section{Experiment $B$}

This experiment was conducted to determine the effect of varying the time of administration of $\mathrm{Gn}-\mathrm{RH}$, relative to the time of sponge removal, on the time of ovulation in ewes treated with progesterone-impregnated sponges and PMSG.

A flock of 145 Galway ewes, aged 3-6 years, was treated for 12 days with progestagen impregnated sponges beginning on 16 August or 2 September 1975. At the time of sponge removal all ewes received 500 i.u. PMSG and were divided at random into 3 groups which were then treated as follows: Group 1 received $50 \mu \mathrm{g}$ Gn-RH $24 \mathrm{~h}$ after sponge removal; Group 2 received $50 \mu \mathrm{g} \mathrm{Gn}-\mathrm{RH} 48 \mathrm{~h}$ after sponge removal; and Group 3 received no further treatment. The ewes in each treatment group were allocated at random to 1 of 5 sub-groups according to the time of ovarian inspection by laparoscopy, at $48,58,68,78$ and $88 \mathrm{~h}$ after sponge removal, for determination of ovulation. The time of onset and duration of oestrus was established by checking all ewes individually for the presence of oestrus at 4-h intervals beginning at $24 \mathrm{~h}$ after sponge removal. A large pool of rams was available for this purpose. Ovulation rate was assessed at laparoscopy or when the ewes were slaughtered 7-10 days after sponge withdrawal.

\section{Experiment $C$}

The effects of Hoe 766 on the occurrence of oestrus and ovulation rate in ewes treated with progestagen sponges during the breeding season were studied.

On 26 November 1976 progestagen-impregnated sponges were inserted into 79 mature ewes which were then allocated at random to 7 groups. The first 6 groups were assigned to a $3 \times 2$ factorial experiment in which three doses of Hoe $766(2,4$ and $8 \mu \mathrm{g})$ were compared at two times 
of administration relative to the time of sponge removal, i.e. at 2 days before (Day -2: Groups 1,2 and 3) or at the time of (Day 0: Groups 4, 5 and 6) sponge removal. The remaining ewes served as controls (Group 7). Vasectomized rams were raddled and placed among the ewes at sponge removal and the flock was checked once daily for 6 days for evidence of oestrus. Ovulation rate was assessed at laparoscopy on the 7 th day after sponge withdrawal.

\section{Experiment $D$}

The effect of time of administration of Hoe 766, relative to the end of progestagen treatment, on the release of $\mathrm{LH}$ and the occurrence of ovulation was studied.

Thirty-one ewes, which had been used in Exp. C, were treated with progestagen-impregnated sponges for 12 days from 14 January 1977 and divided into 3 groups for treatment as follows: ewes in Group 1 received $4 \mu \mathrm{g}$ Hoe $76648 \mathrm{~h}$ before sponge removal; ewes in Group 2 received 4 $\mu \mathrm{g}$ Hoe 766 at the time of sponge removal and those in Group 3 served as controls. Blood samples were taken from all ewes in Group 1 and from 7 ewes in each of Groups 2 and 3, at 30min intervals during the first $2 \mathrm{~h}$ after injection of Hoe 766 into the ewes in Group 1. During the first $2 \mathrm{~h}$ after sponge removal blood samples were taken from all ewes in each group at 30-min intervals and at 2 -h intervals thereafter until the 12 th hour after sponge withdrawal. The ovaries of all ewes were inspected at laparoscopy between 30 and $35 \mathrm{~h}$ after sponge removal to determine whether ovulation had occurred; the actual ovulation rate was assessed at a second inspection 11 days later. Raddled teaser rams were run with the ewes for 6 days after sponge removal and the flock was inspected daily for fresh raddle marks.

Plasma was prepared from the blood samples and LH was measured by using a double antibody radioimmunoassay with NIH-LH-S18 as standard and LER 1374A for iodination (Hanrahan, Quirke \& Gosling, 1977). The antiserum was kindly supplied by Dr G. Jenkin (rabbit anti-ovine $\mathrm{LH}$ absorbed with $\mathrm{TSH}, \mathrm{DB5} / 5$ ). The sensitivity, as calculated from the error in the amount of label bound at zero standard (twice s.d.) and the slope for each assay run, was $0.12 \pm 0.04 \mathrm{ng} \mathrm{LH} / \mathrm{ml}$ (mean \pm s.e.m., $n=4$ ). The assay of $1000 \mathrm{pg}$ and $5000 \mathrm{pg}$ quantities of standard added to a plasma sample with low concentrations of LH gave mean recoveries of 102 and $98 \%$ respectively. The intra- and inter-assay coefficients of variation for levels of $1.3,11.4$ and $50 \cdot 5 \mathrm{ng} \mathrm{LH} / \mathrm{ml}$ were $17 \cdot 3,5 \cdot 7,18 \cdot 9$ and $11 \cdot 8,6 \cdot 0$ and $17 \cdot 2 \%$, respectively.

\section{Experiment $E$}

The purpose of this experiment was to determine whether ovulation occurred, in response to a single injection of a Gn-RH analogue, in ewes being treated with progestagen-impregnated sponges.

Sponges were inserted into 30 mature ewes on 5 August 1977. After 10 days, while the sponges were still in situ, the ewes were divided into 5 groups for treatment as follows: Groups 1 and 2 received 4 and $8 \mu \mathrm{g}$ Hoe 766, respectively, Groups 3 and 4 received 4 and $8 \mu \mathrm{g} \mathrm{AY}-25,205$ respectively, and Group 5 had no treatment and served as a control.

The reproductive organs of all ewes were recovered at slaughter $48 \mathrm{~h}$ after injection and the ovaries were inspected for ovulation. Raddled rams were run with the ewes between the 10th day after sponge insertion and slaughter.

\section{Experiment $F$}

In this experiment the occurrence of oestrus and conception was studied in ewes after treatment with progestagen-impregnated sponges and $\mathrm{Gn}-\mathrm{RH}$ analogues.

Sponges were inserted into a flock of 55 mature ewes and the animals were divided at random into 9 groups on 5 August 1977. The experiment was factorial in design and consisted of a comparison of the effects of two doses (4 (Groups 1-4) and 8 (Groups 5-8) $\mu \mathrm{g}$ ) of Hoe 766 (Groups 1, 2, 5 and 6) and AY-25,205 (Groups 3, 4, 7 and 8) given either 2 days before (Groups 
$1,3,5$ and 7) or at the time of sponge removal (Groups 2, 4, 6 and 8) with Group 9 being kept as a control. Fertile rams were raddled and run with the flock for the first 6 days after sponge withdrawal during which period the flock was checked daily for evidence of mating. Pregnancy rates were established at slaughter, 26 days after sponge removal.

\section{Statistical analyses}

The continuous data were analysed by using least squares procedures while differences in class frequencies were tested by the G-test procedure of Sokal \& Rholf (1969).

\section{Results}

\section{Experiment $A$}

The numbers of ewes treated, together with the oestrus and ovarian responses in each of the 4 groups are summarized in Table 1. All aspects of the results were similar for the ewes treated during February and May. The proportion of ewes which experienced oestrus was significantly greater $(P<0.05)$ in Group 1 than in any of the other 3 groups. The proportion of ewes which ovulated in Groups 3 and 4 did not differ significantly from that in Group 1, but that in Group 2 was lower $(P<0.05)$. The ovulation rates in Groups 1 and 2 were similar and lower than the values for Groups 3 and 4 . The F-test for differences among the four groups was significant $(P<$ 0.05 ). Ovulation rate was not influenced in any group by the timing of the laparoscopic examinations but the time of occurrence of ovulation after sponge removal did differ significantly $(P<0.01)$ among the treatments (Table 2).

Table 1. Oestrus and ovarian responses of ewes in Exp. A

\begin{tabular}{lcccc}
\hline & $\begin{array}{c}\text { Group 1 } \\
\text { (PMSG) }\end{array}$ & $\begin{array}{c}\text { Group 2 } \\
\text { (PMSG + Gn-RH) }\end{array}$ & $\begin{array}{c}\text { Group 3 } \\
\text { (PMSG + hCG) }\end{array}$ & $\begin{array}{c}\text { Group 4 } \\
\text { (PG 600) }\end{array}$ \\
\hline $\begin{array}{l}\text { No. of ewes treated } \\
\text { No. in oestrus (\%) }\end{array}$ & 66 & 64 & 65 & 60 \\
$\begin{array}{l}\text { Interval (mean } \pm \text { s.e.m.) from } \\
\text { sponge removal to onset of } \\
\text { oestrus (h) }\end{array}$ & $55(83)$ & $33(52)$ & $41(63)$ & $39(65)$ \\
$\begin{array}{l}\text { No. of ewes ovulating (\%)* } \\
\begin{array}{l}\text { Ovulation rate } \dagger \\
\text { (mean } \pm \text { s.e.m.) }\end{array}\end{array}$ & $\begin{array}{c}46.7 \pm 2 \cdot 1 \\
63(96)\end{array}$ & $49.0 \pm 2 \cdot 4$ & $47 \cdot 0 \pm 2 \cdot 1$ & $47.9 \pm 2.2$ \\
\hline
\end{tabular}

* Ewes with one or more CL in their ovaries at 7-14 days after sponge removal.

$\dagger$ Per ewe which ovulated.

Table 2. Percentages of ewes ovulating (no. in parentheses) at times relative to vaginal sponge removal in ewes in Exp. A

\begin{tabular}{|c|c|c|c|c|c|}
\hline \multirow[b]{2}{*}{ Group } & \multicolumn{5}{|c|}{ Interval (h) } \\
\hline & 48 & 58 & 68 & 78 & 88 \\
\hline 1 (PMSG) & $0.0(12)$ & $36.4(11)$ & $68.8(16)$ & $93 \cdot 8(16)$ & $100 \cdot 0(8)$ \\
\hline $2($ PMSG + Gn-RH) & $46 \cdot 2(13)$ & $100 \cdot 0(11)$ & $78 \cdot 6(14)$ & $88.9(9)$ & $100 \cdot 0(6)$ \\
\hline $3(\mathrm{PMSG}+\mathrm{hCG})$ & $8 \cdot 3(12)$ & 36.4 (11) & $86 \cdot 7(15)$ & $100 \cdot 0(13)$ & $100 \cdot 0(8)$ \\
\hline 4 (PG 600) & $8 \cdot 3(12)$ & $21.4(14)$ & $33 \cdot 3(12)$ & $100 \cdot 0(11)$ & $100.0(8)$ \\
\hline
\end{tabular}

Ewes which did not have one or more $\mathrm{CL}$ in their ovaries at 7-14 days after sponge removal are not included. 


\section{Experiment $B$}

There were no significant differences between the treatments with respect to any of the variables measured (Table 3). The timing of the laparoscopic examinations did not influence either the duration of oestrus or ovulation rate. The data relating to the timing of the occurrence of ovulation after sponge removal are given in Table 4. The principal feature of the results was the difference among the treatments with respect to the proportion of ewes which had ovulated by $58 \mathrm{~h}$ after sponge removal. In Group 1 over $44 \%$ of the ewes had ovulated by $48 \mathrm{~h}$ and all had done so by $58 \mathrm{~h}$. In Groups 2 and 3, however, ovulation was not observed in any sheep at $48 \mathrm{~h}$ and $100 \%$ ovulation was not recorded until $88 \mathrm{~h}$ and $78 \mathrm{~h}$ respectively. The time pattern of ovulation was significantly altered by injection of Gn-RH at $24 \mathrm{~h}$ after sponge removal $(P<$ $0 \cdot 05)$.

Table 3. Oestrus and ovarian responses of ewes in Exp. B $(50 \mu \mathrm{g} \mathrm{Gn-RH}$ at $24 \mathrm{~h}$ (Group 1) or $48 \mathrm{~h}$ (Group 2) after sponge removal)

\begin{tabular}{lccc}
\hline & $\begin{array}{c}\text { Group 1 } \\
\text { (Gn-RH 24 h) }\end{array}$ & $\begin{array}{c}\text { Group 2 } \\
\text { (Gn-R 48 h) }\end{array}$ & $\begin{array}{c}\text { Group 3 } \\
\text { (control) }\end{array}$ \\
\hline No. of ewes & 48 & 50 & 47 \\
No. in oestrus (\%) & $47(98)$ & $50(100)$ & $46(98)$ \\
$\begin{array}{l}\text { Interval (mean } \pm \text { s.e.m.) from sponge } \\
\quad \text { removal to onset of oestrus (h) }\end{array}$ & $32.6 \pm 0.94$ & $32.4 \pm 0.93$ & $33.0 \pm 0.96$ \\
No. of ewes ovulating (\%) & $45(94)$ & $50(100)$ & $46(98)$ \\
Ovulation rate (mean \pm s.e.m.) & $1.94 \pm 0.13$ & $1.74 \pm 0.13$ & $1 \cdot 81 \pm 0.14$ \\
Mean \pm s.e.m. duration of oestrus (h) & $34.8 \pm 2.3$ & $34.5 \pm 2.3$ & $32.7 \pm 2.4$ \\
\hline
\end{tabular}

Table 4. Effect of the time of administration of $\mathrm{Gn}-\mathrm{RH}$ on the percentage of ewes ovulating at various times after sponge removal in Exp. B (no. of ewes in parentheses)

\begin{tabular}{lccccc}
\hline & \multicolumn{5}{c}{ Interval (h) } \\
\cline { 2 - 6 } \multicolumn{1}{c}{ Group } & 48 & 58 & 68 & 78 & \multicolumn{1}{c}{88} \\
\hline 1(Gn-RH 24 h) & $44(9)$ & $100(10)$ & $100(8)$ & $100(9)$ & $100(9)$ \\
2 (Gn-RH 48 h) & $0(10)$ & $60(10)$ & $90(10)$ & $90(10)$ & $100(10)$ \\
3 (control) & $0(10)$ & $67(9)$ & $80(10)$ & $100(8)$ & $100(9)$ \\
\hline
\end{tabular}

Four ewes which did not have one or more $\mathrm{CL}$ in their ovaries at $7-10$ days after sponge removal were not included.

\section{Experiment $C$}

Neither the incidence of oestrus nor the ovarian response depended on the dose of Hoe 766 $(P>0.05)$ and hence the data were pooled for the different doses $(2,4$ and $8 \mu \mathrm{g})$ at each time (Groups 1-3 and Groups 4-6) and are presented in Table 5. Fewer ewes experienced oestrus after the Hoe 766 treatment at the time of sponge removal than in either of the other two groups $(P<0.05)$, but the distribution of the onset of oestrus after sponge removal was similar in the three groups. The average ovulation rate was higher in ewes receiving Hoe 766 but the difference from the controls was significant only for the animals treated before sponge removal $(t=2.02$; $P<0.05$ ).

\section{Experiment D}

The oestrus and ovarian responses of the ewes are shown in Table 6. Fewer ewes in Group 2 had an overt oestrus compared with those in the other two groups. None of the ewes in Group 3 had ovulated at 30-35 h after sponge removal. The numbers of ewes ovulating by $30-35 \mathrm{~h}$ after 
Table 5. Oestrus and ovarian responses of ewes treated with 2, 4 or $8 \mu \mathrm{g}$ Hoe 766 either 2 days before (Day -2: Groups 1-3) or at the time of removal (Day 0: Groups 4-6) of the vaginal sponges (Exp. C)

\begin{tabular}{lccc}
\hline & & \multicolumn{2}{c}{ Hoe 766 } \\
\cline { 3 - 4 } & $\begin{array}{c}\text { Control } \\
\text { (Group 7) }\end{array}$ & $\begin{array}{c}\text { Day -2 } \\
\text { (Groups 1-3) }\end{array}$ & $\begin{array}{c}\text { Day 0 } \\
\text { (Groups 4-6) }\end{array}$ \\
\hline $\begin{array}{l}\text { No. of ewes } \\
\text { No. in oestrus (\%) }\end{array}$ & 12 & 33 & 34 \\
$\begin{array}{l}\text { Distribution of the onset of oestrus after sponge } \\
\text { removal: }\end{array}$ & $11(92)$ & $31(94)$ & $15(44)$ \\
$\quad$ 2-3 days & & & \\
$\quad$ 4-6 days & 9 & 19 & 8 \\
No. of ewes ovulating (\%) & 2 & 12 & 7 \\
Ovulation rate (mean \pm s.e.m.) & $12(100)$ & $33(100)$ & $34(100)$ \\
\hline
\end{tabular}

Table 6. Oestrus and ovulation responses of ewes treated with $4 \mu \mathrm{g}$ Hoe 766 either 2 days before (Day -2: Group 1) or at the time of removal (Day 0: Group 2) of vaginal sponges (Exp. D)

\begin{tabular}{|c|c|c|c|}
\hline & \multirow[b]{2}{*}{$\begin{array}{l}\text { Controls } \\
\text { (Group 3) }\end{array}$} & \multicolumn{2}{|c|}{ Hoe 766} \\
\hline & & $\begin{array}{c}\text { Day -2 } \\
\text { (Group 1) }\end{array}$ & $\begin{array}{c}\text { Day 0 } \\
\text { (Group 2) }\end{array}$ \\
\hline No. of ewes & 14 & 13 & 13 \\
\hline No. in oestrus (\%) & $12(86)$ & $8(62)$ & $4(31)$ \\
\hline $\begin{array}{l}\text { Distribution of the onset of oestrus after } \\
\text { sponge removal: } \\
2-3 \text { days } \\
4-6 \text { days }\end{array}$ & $\begin{array}{r}11 \\
1\end{array}$ & $\begin{array}{l}5 \\
3\end{array}$ & $\begin{array}{l}0 \\
4\end{array}$ \\
\hline $\begin{array}{l}\text { No. of ewes ovulating (\%) } \\
30-35 \mathrm{~h}^{*} \\
12 \text { th day* }\end{array}$ & $\begin{array}{c}0 \\
14(100)\end{array}$ & $\begin{array}{c}8(62) \\
13(100)\end{array}$ & $\begin{array}{c}8(62) \\
12(92)\end{array}$ \\
\hline Ovulation rate (12th day) (mean \pm s.e.m.) & $1 \cdot 14 \pm 0 \cdot 10$ & $1.25 \pm 0.16$ & $1 \cdot 13 \pm 0.13$ \\
\hline
\end{tabular}

* After sponge removal.

sponge removal differed significantly $(P<0.05)$ in Group 3 compared with each of the other groups.

Oestrus was not observed in any ewe before $30-35 \mathrm{~h}$ after sponge removal. Of the 8 ewes in Group 1 which had ovulated at $30-35 \mathrm{~h}$ after sponge removal, 3 subsequently came into oestrus but none of the animals in Group 2 which had recently ovulated at 30-35 h after sponge removal subsequently experienced oestrus.

The plasma LH levels in the three groups are shown in Text-fig. 1. LH levels increased significantly $(P<0.01)$ after injection of the analogue and the responses were similar in Groups 1 and 2 during the first $2 \mathrm{~h}$. Plasma LH remained at basal levels throughout the sampling period on Day 0 in one ewe in Group 2 and this animal has been excluded from Text-fig. 1.

\section{Experiment $E$}

None of the ewes from Group 5 (control) had ovulated at autopsy. Some ewes had ovulated in all of the remaining groups but the proportion was similar for the two analogues and was not influenced by the dose given. Twelve of the 24 ewes (50\%) injected with the analogues had ovulated at slaughter. None of the ewes experienced oestrus. 


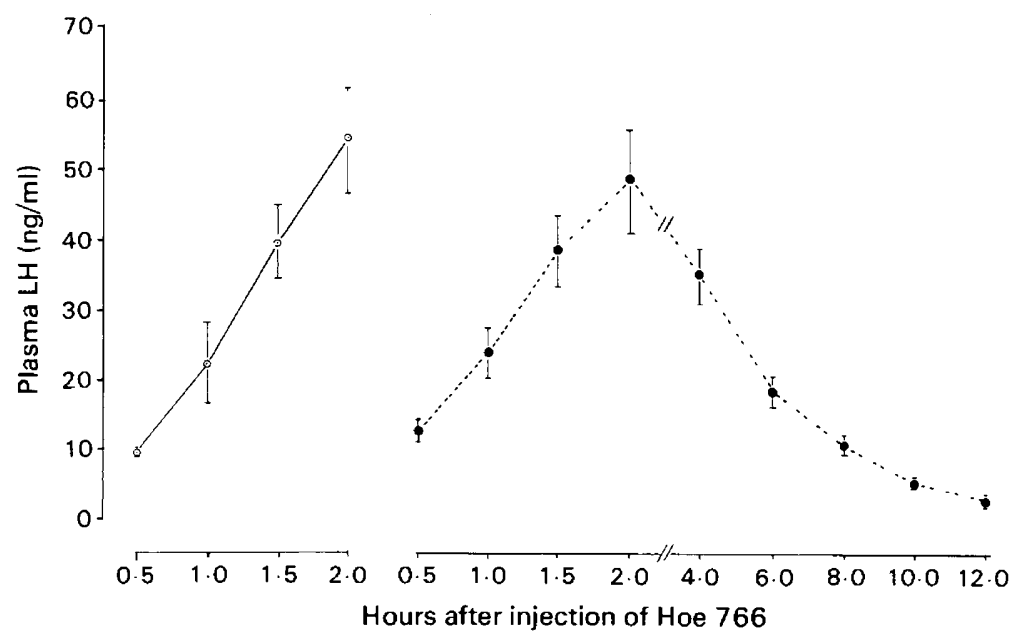

Text-fig. 1. Plasma LH levels in ewes treated with $4 \mu \mathrm{g}$ of the Gn-RH analogue Hoe 766 either 2 days before (Day -2: Group 1, O- -13 ewes) or at the time of sponge removal (Day 0: Group 2, -- 12 ewes). Values are means \pm s.e.m. Values for the control ewes and those treated on Day -2 and sampled on Day 0 were always less than $4 \mathrm{ng} / \mathrm{ml}$ and have been excluded for clarity.

\section{Experiment $F$}

The incidence of oestrus and conception rate were similar for the two analogues (Hoe 766 and AY-25,205) and were not influenced by the different doses $(4$ and $8 \mu \mathrm{g})$ employed $(P>$ 0.05 ). The combined results in relation to the time of administration of the releasing hormones are in Table 7. The incidence of oestrus was significantly lower $(P<0.01)$ in ewes treated with the analogues at the time of sponge removal than for the controls or for ewes treated before sponge removal. The percentage of mated ewes which became pregnant was similar for all groups.

Table 7. Effect of Gn-RH analogues (Hoe 766 and AY-25,205) on the fertility of ewes treated 2 days before (Day -2: Groups 1, 3, 5 and 7) or at the time of removal (Day 0: Groups 2, 4, 6 and 8) of vaginal sponges (Exp. F)

\begin{tabular}{lccc}
\hline & & \multicolumn{2}{c}{ Gn-RH analogues } \\
\cline { 3 - 4 } & Controls & Day -2 & Day 0 \\
\hline $\begin{array}{l}\text { No. of ewes treated } \\
\text { No. of ewes in oestrus (\%) }\end{array}$ & 11 & 21 & 23 \\
$\begin{array}{l}\text { Distribution of the onset of oestrus after sponge } \\
\text { removal: }\end{array}$ & $10(91)$ & $19(90)$ & $13(57)$ \\
$\quad \begin{array}{l}\text { 2-3 days } \\
\quad \text {-6 days }\end{array}$ & 10 & 16 & 3 \\
No. of pregnant ewes (\%)* & 0 & 3 & 10 \\
No. of embryos per pregnant ewe (mean \pm s.e.m.) & $1.43 \pm 0.20$ & $1.17 \pm 0.11$ & $1.50 \pm 0.27$ \\
\hline
\end{tabular}

* Of ewes mated.

\section{Discussion}

One of the objectives of Exps A and B, namely the precise control of the time of ovulation in relation to the time of removal of progestagen sponges, was not achieved with any of the treatments employed. Gn-RH, however, would appear to have some promise as an agent for 
controlling the exact timing of ovulation in the ewe. In both Exps A and B, Gn-RH given $24 \mathrm{~h}$ after sponge removal had induced ovulation in $44-46 \%$ of ewes within $24 \mathrm{~h}$ and in $100 \%$ by $58 \mathrm{~h}$ after sponge removal while none of the control ewes had ovulated by $48 \mathrm{~h}$ and only $36-67 \%$ by $58 \mathrm{~h}$. It is also possible that the control of the time of ovulation in ewes treated with Gn-RH $24 \mathrm{~h}$ after sponge removal was even more precise than the ovarian inspections indicated. Cumming $e t$ al. (1973) have shown that the interval between the LH surge and release of the egg from the follicle can vary from 21 to $26 \mathrm{~h}$. Ovarian inspections at, say, 45 and $50 \mathrm{~h}$ after sponge removal would be therefore required to determine the real efficiency of this treatment protocol for the control of the time of ovulation.

Treatment with Gn-RH at $48 \mathrm{~h}$ after sponge removal is clearly too late for any effect on the occurrence of ovulation since the time of ovulation has probably already been determined for the majority of the ewes by the spontaneous preovulatory LH discharge.

The efficiency of hCG for controlling the time of ovulation in ewes treated with progestagenimpregnated intravaginal sponges and PMSG has not previously been reported. Some authors (Braden, Lamond \& Radford, 1960; Dziuk, 1965; Roche \& Crowley, 1971) have reported good control of ovulation following the use of hCG in conjunction with progestagens administered by the intramuscular, oral and subcutaneous routes. The present results, however, are in agreement with those of Killeen \& Moore (1970) who found that hCG given within $3 \mathrm{~h}$ of the onset of oestrus did not reduce the range in time of ovulation in Merino ewes which had been primed with PMSG on the 12th day of the oestrous cycle. The FSH-activity of hCG is well known and may be reflected in the higher ovulation rates in Groups 3 and 4 in Exp. A.

Suppression of oestrus in a high proportion of animals is a feature of the results of many experiments in which hCG has been used for the control of ovulation in farm animals (Braden $e t$ al., 1960; Roche \& Crowley, 1973). This effect was also apparent in the present work. It would appear that $\mathrm{Gn}-\mathrm{RH}$ can also adversely influence the expression of oestrus in some circumstances (Exp. A). The absence of any effect of Gn-RH on the occurrence of oestrus in Exp. B may be due to differences in the timing of its administration relative to the expected time of onset of oestrus in the two experiments. The interval between sponge removal and the onset of oestrus was longer for ewes treated during February and May (Exp. A) than for those treated during August and September (Exp. B), which agrees with the results of several other authors (Holst, 1969; Boshoff, van Niekerk \& Morgenthal, 1973). This seasonal variation would also suggest that the timing of administration of ovulation inducers, such as $\mathrm{Gm}-\mathrm{RH}$, relative to the time of sponge removal should perhaps be later in the anoestrum than during the breeding season for best control of ovulation.

Findlay \& Cumming (1976) have reported that Hoe 766 given to ewes on Day 12.5 of the cycle increased the ovulation rate but that the expression of oestrus was adversely affected. The results of our Exp. $C$ show that this analogue is also capable of increasing ovulation rate in progestagen-treated ewes and that the expression of oestrus was not influenced when Hoe 766 was given 2 days before the removal of the sponges. The mechanism whereby ovulation rate is increased is unclear. Findlay \& Cumming (1976) have suggested that the increase in ovulation rate arises because of increased follicular growth caused by the release of FSH in response to the Gn-RH analogue. It is clear from the results of Exps D and E, however, that the release of LH in response to the Gn-RH analogues is of sufficient magnitude and duration to trigger ovulation immediately in a high proportion of ewes (50-62\%), irrespective of the time of administration relative to sponge removal. If ovulation has already been induced in $\geqslant 50 \%$ of ewes at the time of sponge removal by an injection of an analogue 2 days earlier (as in Exp. E) and yet the majority of ewes so treated come into oestrus after sponge removal (see Table 5), then it seems reasonable to conclude that additional ova are shed at the time of oestrus, thereby augmenting the ovulation rate subsequently observed. Indeed, the short functional life-span of the unfertilized sheep egg makes it essential that ewes which ovulate in response to $\mathrm{Gn}-\mathrm{RH}$ analogues while still being treated with progestagen-impregnated sponges should also ovulate again at the oestrus 
subsequent to sponge removal, otherwise conception would be most unlikely to occur. Conception rate was not influenced by the time of administration of the Gn-RH analogues (Exp. F), indicating that supplementary ovulations did in fact occur at oestrus in many ewes which had received analogues before sponge removal.

It is known that the high levels of LH secreted at oestrus are responsible for termination of oestrogen secretion by the preovulatory follicle which subsequently becomes converted into a secretor of progesterone and develops into the corpus luteum (Moor, 1974). It is possible that the failure of a high proportion of ewes to come into oestrus following administration of $\mathrm{Gn}-\mathrm{RH}$ analogues at the time of sponge removal may be due to alterations in the timing of hormonal events. Thus in Exp. D (Group 2) a Gn-RH analogue given at this time caused an immediate LH surge (Text-fig. 1). This LH discharge triggered ovulation in a high proportion of ewes and these events, presumably, prevented the preovulatory rise in oestrogen levels necessary for the display of oestrus. The expression of oestrus subsequent to sponge removal, however, was not affected in ewes treated with analogues 2 days before sponge removal (Exp. D, Group 1) despite the occurrence of an $\mathbf{L H}$ peak and precocious ovulation. This would suggest that the majority of postovulatory follicles and $\mathrm{CL}$ produced at this time do not secrete progesterone, a situation similar to that reported for anoestrous ewes after treatment with Gn-RH (Haresign, Foster, Haynes, Crighton \& Lamming, 1975). It is possible that the normal luteotrophic stimulus, a combination of LH and prolactin (Denamur, Martinet \& Short, 1973; Denamur, 1974), is absent in these circumstances and that the low levels of progesterone after sponge removal facilitated the release of endogenous gonadotrophins and that oestrus and ovulation followed.

The results of these experiments indicate that further research is needed before Gn-RH or its analogues can be considered as practical aids to control the timing or rate of ovulation in sheep.

We thank Mr W. Loughnane, Mr T. Lally, Mr J. McWeeney and Mr G. McLoughlin for their excellent technical assistance; Dr R. Mauer, Abbott Laboratories; Dr U. K. Banik, Ayerst Research Laboratories, and Dr K. Seeger, Hoechst Ltd, for gifts of Gn-RH and Gn-RH analogues; and NIAMDD, Bethesda, Maryland, U.S.A., for purified ovine LH.

\section{References}

Boshoff, D.A., van Niekerk, C.H. \& Morgenthal, J.C. (1973) Time of ovulation in the Karakul ewe following synchronization of oestrus. S. Afr. J. A nim. Sci. 3, 13-17.

Braden, A.W.H., Lamond, D.R. \& Radford, H.M. (1960) The control of the time of ovulation in sheep. Aust. J. agric. Res. 11, 389-401.

Cruz, A. De La, Cruz, K.G. De La, Arimura, A., Coy, D.H., Vilchez-Martinez, J.A., Coy, E.J. \& Schally, A.V. (1975) Gonadotrophin-releasing activity of two highly active and long acting analogs of luteinizing hormone-releasing hormone after subcutaneous, intravaginal and oral administration. Fert. Steril. 26, 894-900.

Cumming, l.A., Buckmaster, J.M., Blockey, M.A. de B., Goding, J.R., Winfield, C.G. \& Baxter, R.W. (1973) Constancy of interval between luteinizing hormone release and ovulation in the ewe. Biol. Reprod. 9, 2429.

Denamur, R. (1974) Luteotrophic factors in the sheep. $J$. Reprod. Fert. 38, 251-259.

Denamur, R., Martinet, J. \& Short, R.V. (1973) Pituitary control of the ovine corpus luteum. J. Reprod. Fert. 32, 207-220.
Dziuk, P.J. (1965) Timing of maturation and fertilization of the sheep egg. Anat. Rec. 153, 211-223.

Findlay, J.K. \& Cumming, I.A. (1976) Increase in ovulation rate in sheep following administration of an LHRH analogue. Biol. Reprod. 15, 115-117.

Fujino, M., Yamazaki, I., Kobayashi, S., Fukuda, S., Shinagawa, S., Nakayama, R., White, W.F. \& Ripple, R.H. (1974) Some analogs of luteinizing hormone releasing hormone (LH-RH) having intense ovulation-inducing activity. Biochem. Biophys. Res. Commun. 57, 1248-1256.

Haresign, W., Foster, J.P., Haynes, N.B., Crighton, D.B. \& Lamming, G.E. (1975) Progesterone levels following treatment of seasonally anoestrous ewes with synthetic LH-releasing hormone. J. Reprod. Fert. 43, 269-279.

Hanrahan, J.P., Quirke, J.F. \& Gosling, J.P. (1977) Genetic and non-genetic effects on plasma $\mathrm{LH}$ concentrations in lambs at 4 and 8 weeks of age. $J$. Reprod. Fert. 51, 343-349.

Holst, P.J. (1969) The ovarian response to pregnant mare serum (PMSG) administered after intravaginal progestagen treatment of cyclic and anoestrous ewes. Aust. J. agric. Res. 20, 1143-1150. 
Killeen, 1.D. \& Moore, N.W. (1970) The effect of pregnant mare serum gonadotrophin and human chorionic gonadotrophin on ovulation and on fertility in the ewe. Aust. J. agric. Res. 21, 807-814.

Kinder, J.E., Adams, T.E., Nett, T.M., Coy, D.H., Schally, A.V. \& Reeves, J.J. (1976) Serum gonadotrophin concentrations and ovarian response in ewes treated with analogs to LH-RH/FSH-RH. $J$. Anim. Sci. 42, 1220-1226.

Moor, R.M. (1974) The ovarian follicle of the sheep: inhibition of oestrogen secretion by luteinizing hormone. J. Endocr. 61, 455-463.

Nalbandov, A.V. (1958) Reproductive Physiology, pp. 125-126. W. H. Freeman \& Co., San Francisco.

Pelletier, J. (1976) Influence of LH-RF on LH and FSH releases in domestic animals. Annls Biol. anim. Biochim. Biophys. 16, 213-234.

Ripple, R.H., Johnson, E.S., White, W.F., Fujino, M., Yamazaki, I. \& Nakayama, R. (1973) Ovulating and LH-releasing activity of a highly potent analogue of synthetic gonadotrophin-releasing hormone. Endocrinology 93, 1449-1452.

Ripple, R.H., Moyer, R.H., Johnson, E.S. \& Mauer, R.E.
(1974) Response of the ewe to synthetic gonadotrophin releasing hormone. J. Anim. Sci. 38 , $605-612$.

Roche, J.F. \& Crowley, J.P. (1971) The effect of controlling the interval from mating to ovulation on pregnancy rate in ewes treated with progesterone. $J$. Reprod. Fert. 24, 307-309.

Roche, J.F. \& Crowley, J.P. (1973) The fertility of heifers inseminated at predetermined intervals following treatment with $\mathrm{MGA}$ and $\mathrm{HCG}$ to control ovulation. J. Reprod. Fert. 35, 211-216.

Sokal, R.R. \& Rholf, FJ. (1969) Biometry. W. H. Freeman \& Co., San Francisco.

Symons, A.M., Cunningham, N.F. \& Saba, N. (1974) The gonadotrophic hormone response of anoestrous and cyclic ewes to synthetic luteinizing hormonereleasing hormone. J. Reprod. Fert. 39, 11-21.

Willis, K.J., London, D.R., Williams, J.W. \& Butt, W.R. (1976) A comparative study of synthetic gonadotrophin releasing hormone decapeptide with a synthetic analogue (des-GLY- $\mathrm{NH}_{2}^{10}$-pro-ethylamide) of luteinizing hormone/follicle-stimulating hormone releasing hormone. J. Endocr. 70, 147-148.

Received 11 September 1978 